\title{
UNIVERSITY EDUCATION OF REGULATION OF THE TRANSACTIONS EXECUTED VIA INTERNET (BASED ON RUSSIAN EXAMPLES)
}

\author{
Ivan Nikolaievich Chumachenko \\ $\mathrm{PhD}$ in Law, Institute of Law, Peoples' Friendship University of Russia (RUDN University), \\ Moscow, RUSSIA, ivan26061989@mail.ru
}

\begin{abstract}
Legal subjects are one of the major disciplines taught at the Law Institute of the Peoples' Friendship University of Russia (RUDN University). Our professors and lecturers constantly research and thoroughly monitor the educational methodology in foreign countries and consider the new trends in legal education an integral part of the educational process. This article is the result of such research.

In the 21st century, transactions executing in the global network are becoming more and more widespread, threatening to leave traditional transactions signed on paper in history, even though such a method of concluding transactions has appeared quite recently (the first prototype network "Internet" - "ARPANET" was created in the late 60s). In contrast to the practical prevalence of such transactions, there is a fairly large number of questions regarding their legal status, legal nature, as well as content. Moreover, the judicial and extrajudicial protection is not always clear as well as issues related to the recognition of such transactions as they may be concluded. Besides, the question of the choice of applicable law in the framework of the transaction through the Internet has high level of interest for parties of the transaction. Understanding of the ways of the resolving this problem will subsequently allow the parties to determine the appropriate rules of substantive law applicable to a particular transaction. The conclusion of transactions via the Internet raised the question of the methods of confirmation / identification the qualifications of signatories, persons authorized to conclude certain transactions. In this regard, in recent years, using of the so-called electronic digital signature has become widespread, despite some technical problems associated with decoding such a signature and its utilization.
\end{abstract}

The article will help to shift the process of learning and teaching in Russian universities if they are eager to move ahead "armed" with the necessary knowledge in the rapidly changing education market.

Keywords: legal education, higher education, Internet, conflict law, e-commerce, electronic signature.

\section{INTRODUCTION}

The ability to conclude transactions remotely (in a distance manner) by electronic means of communication is one of the sources for the development of trade in general, both at the national level and international. At the same time, the constant change in trade (the emergence of new legal relations, changes in old ones), leads to the necessity to improve the current legislation. 
E-commerce (the more common designation for this area of business) as "a sphere of the economy, which includes all financial and trade transactions carried out using computer networks, and the business processes associated with conducting such transactions" is an essential component of e-business (Ecommerce: legal regulation and taxation, 2011). At the same time, in the opinion of the author of this article, a transaction concluded via the Internet is essentially no different from a regular transaction, with the exception of the specifics related to the procedure for its conclusion. At the same time, there are a number of peculiarities associated with the execution and implementation by the parties of their rights under such transactions. This thesis is consistent with the position of M.O. Dyakonova, S.A. Sinitsyn that at the current stage of development, the new technological reality and the state of electronic commerce do not necessitate the formulation of rules in civil legislation on new types and types of civil contracts. The rules and consequences of the written form of the transaction are fully applicable to contracts concluded in digital form (Dyakonova MO, Sinitsyn S.A., 2020). As part of the implementation of transactions via the Internet, a number of questions arise regarding the regulation of the form of the transaction, applicable law, the conclusion (signing) of documents on the transaction, in particular: the applicable law to the transaction, the form of the transaction (or an agreement between the parties), confirmation of the identity or authentification of the signature made by the representative of the party, etc.

The author has based his analysis in relation to these questions on the Russian law. But, at the same time, the author tried to compare some specific norms, precedents of the U.S. law in order to show differences of the regulation under the U.S. and Russian law. However, the author has not made a purpose for himself to make a comparative analysis of all specific issues related to the e-commerce sphere.

\section{MATERIALS AND METHODS}

The main methods in the framework of this study were the dialectic method, the methods of analysis, synthesis and analyses, the comparative legal method, as well as the method of interpretation of legal acts and judicial precedents. The basic method used in the paper is a method of analysis. In order to clarify specific issues which are related to the topic of the research and show its subject, main principles and nature. At the same time, the author used a comparative method of study. By applying of this method the author tried to compare the researches of the different groups of scientists, shown the examples of the different cases of the judicial decisions in order to provide the diversity of the different views on the problem subject to the current research. Not only case law was observed by the authors within this research - the statues related to the problem were also the subject of this research.

\section{RESEARCH RESULTS}

\subsection{Applicable Law to the Electronic Transaction}

In addition to other problems related to the form and procedure for executing transactions on the Internet, a question arises related to the applicable law to the transaction being concluded. A fairly large number of issues depend on the choice of the applicable law, including issues related to the form, procedure for the implementation of the transaction, judicial and extrajudicial methods of protecting violated rights of the parties to such a transaction, as well as many others.

In accordance with article 444 of the Civil Code of the Russian Federation, if the place of its conclusion is not indicated in the contract, the contract is recognized as concluded at the place of residence of the citizen or the location of the legal entity that sent the offer. If we consider a scheme with an offer and acceptance of an offer as part of the implementation of the transaction, then the question arises: what right to apply to such a transaction? What collision binding to use when executing such a transaction? As indicated by N.A. Dmitrik: "The offeror can place the offer not only on a server located in the territory of the state of which he is a resident, but also on a server located anywhere in the world connected to the Internet. The acceptor can send the acceptance from a laptop while in transit (from an aircraft, sea vessel, etc.)."(Dmitrik, 2006).

In accordance with Article 1211 of the Civil Code of the Russian Federation, in the absence of an agreement between the parties on the applicable law, the law of the country where, at the time of the conclusion of the agreement, the place of residence or main place of business of the party that carries out the performance that is decisive for the content of the agreement is located. Consequently, in the event of a transaction being concluded via the Internet, the law of the country in which the person who sent the offer to his potential counterparty is located or permanently resides will apply. Moreover, there is an exception to this rule when it comes to the consumer (Civil Code, 2021).

At the same time, the author of this article cannot agree with the thesis of E.A. Makhinya that "the only possible identifying a legal entity - a participant in civil legal relations, is the address of the Internet site, 
which is used by a specific legal entity in carrying out transactions. The possible criterion for the location of the server has a number of disadvantages due to the ability of the website owner to host the latter on Internet servers located in virtually any country" (Makhinya, 2013). The author of this article stated that the website address is a kind of intermediate link or an external form of expression of the identification of the offer posted on the seller's website. The key way to identify a legal entity, in this case, must be the address of the location / place of registration / place of business / place of residence of the person who sent the offer, as well as its registration number (for a legal entity (if any).

In this regard, the author of this article comes to the conclusion that the Internet is, in fact, exclusively a method of communication / conclusion of a transaction, which does not significantly affect the regulation of the choice of the applicable law in relation to certain transactions concluded via the Internet.

In the United States, the question of applicable law in relation to transactions made on the Internet also plays an important role. One of the most famous precedents in which this issue was addressed was the Mfg. Co. v. Zippo Dot Com, Inc. (Zippo Manufacturing Co. v. Zippo Dot Com, Inc., 1997).

By resolving of this case the court has used a three-prong test for determining whether a court has jurisdiction over a website. In particular it was noted that "the likelihood that personal jurisdiction can be constitutionally exercised is directly proportionate to the nature and quality of the commercial activity that an entity conducts over the Internet."; "If the defendant enters into contracts with residents of a foreign jurisdiction that involve the knowing and repeated transmission of computer files over the Internet, then personal jurisdiction is proper." "A passive website that does little more than make information available to those who are interested in it is not grounds for the exercise of personal jurisdiction." As the result court concluded that "intended object of the transactions had been the downloading of electronic messages that formed the basis of suit in Pennsylvania." These contacts constituted purposeful availment under the threeprong test as Dot Com freely chose to sell its services to residents of Pennsylvania. "Therefore, the Court denied Dot Com's motion to dismiss for lack of jurisdiction (Zippo Manufacturing Co. v. Zippo Dot Com, Inc., 1997).

\subsection{Transaction Form}

In accordance with Article 153 of the Civil Code of the Russian Federation (hereinafter referred to as the "Civil Code of the Russian Federation"), a transaction is recognized as the actions of citizens and legal entities aimed at establishing, changing or terminating civil rights and obligations. When concluding a transaction via the Internet, there must be two parties - the seller and the buyer. Accordingly, such a transaction is a contract. Consequently, taking into account the provisions of clause 3 of Article 154 of the Civil Code of the Russian Federation to conclude an agreement, it is necessary to express the agreed will of two parties (bilateral transaction) or three or more parties (multilateral transaction). This will can be expressed both orally and in writing (Civil Code, 2021).

It should be noted that the provisions of the Civil Code of the Russian Federation equate transactions made with the help of technical means to transactions made in electronic form: signatures are considered completed if any method is used that allows you to reliably identify the person who expressed the will. The law, other legal acts and the agreement of the parties may provide for a special way to reliably determine the person who has expressed his will.

However, this is not the only and not the most common way to execute a transaction via the Internet. The more common way to conclude transactions on the Internet is to conclude an agreement by performing implicit actions. In particular, due to the paragraph 2 of Article 432 of the Civil Code of the Russian Federation, an agreement is concluded by sending an offer (proposal to conclude an agreement) by one of the parties and its acceptance (acceptance of the proposal) by the other party. At the same time, according to clause 3 , a party that has accepted from the other party full or partial performance under the contract or otherwise confirmed the validity of the contract is not entitled to demand the recognition of this contract as not concluded if the statement of such a requirement, taking into account specific circumstances, would contradict the principle of good faith (Civil Code, 2021).

The legislation of the Russian Federation allows notarization of transactions concluded in electronic form. However, this right can be exercised only with the consent of the person who applied for the notarial act. Taking into account this legal prescription, participants in civil relations have the opportunity to notarize the transaction in electronic form. At the same time, notarization of the transaction in electronic form has the same legal force as the traditional paper version of the contract (Proschalygin, 2017).

Art. 44.2 of the Fundamentals on notariat (Federal Constitutional Act of the Russian Federation) provides for 
the possibility of producing a notarial document in electronic form, for example a transaction, which must be signed with an electronic signature in the presence of a notary (Fundamentals of the legislation of the Russian Federation on notariat, 2021).

\subsection{Use of Electronic Signature within the Framework of a Transaction Executed via the Internet}

In fact, an electronic signature is an analogue of a regular (written) signature, that is, a method of authenticating the signatory (party), as well as confirming the expression of will in the process of concluding a transaction.

The concept of a handwritten signature is not enshrined in the civil legislation of the Russian Federation. However, judicial practice in the Russian Federation as a whole follows the path of defining a handwritten signature as a unique set of handwritten characters using certain design techniques that serve to identify a person (Cherepanova, 2020) .

It should be noted that the concept of an electronic signature is enshrined in the legislation of the Russian Federation. In accordance with Art. 2 of the Federal Act dated 06.04.2011 N 63-FZ (revised from 24.02.2021) "On electronic signature" electronic signature - information in electronic form, which is attached to other information in electronic form (signed information) or is otherwise related to such information and which is used to identify the person who signs the information (Federal Act "On electronic signature", 2021).

For the purposes of confirming the ownership of the electronic signature verification key of the owner, the value of the electronic signature verification key certificate, which is determined, is an electronic document or paper document issued by the certification center or a trusted person of the certification center and confirming the ownership of the electronic signature verification key to the owner of the electronic signature verification key certificate.

In Russia, they are currently working on an alternative to an electronic digital signature for identification on the Internet. A plan is being developed to introduce "cloud signature" as an authentication mechanism in the network. The idea is for the user to be able to sign any documents from their mobile device. Its digital signature will not be on a wearable drive, but on a remote cloud resource. Thus, the user is authorized in the cloud resource and then disposes of his electronic signature as he sees fit.

However, despite the emergence and widespread use of the institution of electronic signature in Russia, the issue of signing documents using an electronic signature registered in one country on the territory of another country is still unclear. How should the key certificate of such an electronic signature, created and registered in one country, in the territory of another state, be verified and confirmed? There are no answers to these questions yet. In the opinion of the author of this article, this issue should be resolved at the levels of multilateral agreements on the recognition of electronic signatures and electronic signature certificates issued in one jurisdiction on the territory of all contracting states.

\section{DISCUSSIONS}

The main purpose of this research is to study the main specific issues related to the e-transactions or transactions which have to be executed via internet. As author's point of view, within the execution of the deals in the Internet the parties from time to time cannot clearly specify the law to be applied to such transaction. The author would like to show the some collision methods which could be applied in order to resolve such collisions or to prevent it.

There are a lot of questions which are related to the form of the transaction executing via internet. In general nobody sign any documents in a paper form, but at the same time e-commerce becoming more and more popular way of the international trade. That is why the author would like to clarify a legal status of the transaction form executing via internet.

One of the most important institution or element of the transaction is a signature made on the transaction documents. Each party must have a comfort that provides authentication of the counterparty through an electronic signature. But there are a lot of questions which are related to the legal nature of the electronic signature. The goal of the author is to show some specific issues which are related the abovementioned institution.

\section{CONCLUSIONS}

As part of the study, the author of this article made a number of important conclusions regarding the 
specifics of concluding and implementing transactions via the Internet, in particular, the author noted that the legislation of the Russian Federation does not stand still. As Cherepanova E.V. points out, the dynamic development of the online trading market in the Russian Federation, the consequences of coronavirus infection affecting trade relations, and a number of other factors led to the fact that the Government of the Russian Federation in 2020 began to develop a concept for an experiment for a new model. cross-border ecommerce (Cherepanova E.V., 2020). The Ministry of Finance of the Russian Federation, together with the Federal Customs Service, has prepared a draft concept for the administration of goods transported within the framework of cross-border electronic commerce. It is assumed that such products will be separated into a separate category and the institution of an operator will be created, which will have the rights to perform customs operations (Meeting on the regulation of cross-border electronic commerce, 2017).

In this case, the U.S. approach to the regulation of transactions on the Internet is presented. On the one hand, the United States of America is a country with a free market, within which the principle of noninterference (minimum state interference in private legal (commercial) relations) operates. Under the Clinton administration, recommendations (guidelines) on global electronic commerce were issued in the United States, which also should apply to electronic commerce within the US This document laid down 5 principles in accordance with which electronic commerce should be regulated:

(a) The private sector should be in the lead;

(b) Governments should avoid unreasonable restrictions on electronic commerce;

(c) Where government involvement is necessary, its goal should be to maintain and provide a predictably minimalistic, consistent and simple legal environment for trade;

(d) Governments must recognize the unique qualities of the Internet;

(e) Electronic commerce over the Internet should be facilitated globally (A framework for global electronic commerce, 1997).

\section{ACKNOWLEDGEMENT}

This paper has been supported by the RUDN University Strategic Academic Leadership Program.

\section{REFERENCE LIST}

1. Appeal decision of the Novosibirsk Regional Court dated February 25, 2020 in case No. 2-2660 / 2019 , 33-1893 / 2020 (2020). Retrieved from http://www.consultant.ru [in Rus.]

2. Appeal decision of the Kemerovo Regional Court dated January 23, 2020 in case No. $33-886$ / 2020 (21396 / 2019) (2019). Retrieved from http://www.consultant.ru [in Rus.]

3. Appeal decision of the Leningrad Regional Court dated 09/11/2019 in case No. 33-5452 / 2019 (2019). Retrieved from http://www.consultant.ru [in Rus.]

4. Appeal decision of the Krasnodar Regional Court dated 05/29/2018 in case No. 33-13084 / 2018. (2018). Retrieved from http://www.consultant.ru [in Rus.]

5. Cherepanova, E.V. (2020). Legal experiment as a mechanism for approbation of e-commerce technologies. "International public and private law", N 6, 2020 [in Rus.]

6. Civil Code of the Russian Federation dated on 30.11.1994 (as amended on 09.03.2021). (2021). Retrieved from http://www.consultant.ru [in Rus.]

7. Dmitrik, N. A. (2006). Implementation of subjective civil rights using the Internet. M.: Walters Kluver, (2006). p. 73 [in Rus.]

8. Dyakonova, MO, Sinitsyn S.A. (2020). Development of electronic commerce and the main directions of modernization of civil and procedural legislation. International public and private law ", N 6, (2020) [in Rus.]

9. E-commerce: legal regulation and taxation. Report of the seminar "Guru about the Internet-2011" Internet resource (2011). Retrieved from http://www.mibok.ru/about/press/index.php?ID=1643 
10.Egorova, M.E. (2014). Electronic document as a means of evidence. "Notary", (2014), N 4 [in Rus.]

11.Federal Act "On electronic signature". dated 06.04.2011 N 63-FZ (revised from 24.02.2021) Retrieved from http://www.consultant.ru [in Rus.]

12.Federal Constitutional Act "Fundamentals of the legislation of the Russian Federation on notaries" (approved by the RF Armed Forces on 11.02.1993 N 4462-1) (as amended on 30.12.2020) [in Rus.]

13. Makhinya, E.A. (2013). Actual problems of concluding civil transactions on the Internet. Bulletin of the Omsk Law Academy. Omsk. 2013. No. 2 (21) p. 71 [in Rus.]

14. Meeting on the regulation of cross-border electronic commerce. (2017) // Official portal of the Government of the Russian Federation. Retrieved from: http://government.ru/news/40105/ [in Rus.]

15.Proschalygin, R.A. (2017). Legal regulation of notarization of transactions in electronic form. "Notary", (2017), N 5 [in Rus.]

16.Shmatko S.G., Shumakova Yu.A. (2019). The role of electronic digital signature in modern conditions // In the collection: Russia, Europe, Asia: digitalization of the global space. Collection of scientific papers of the II International Scientific and Practical Forum. Edited by V.A. Queen. (2019). p. 166-168. [in Rus.]

17. The White House, A framework for global electronic commerce (1997). Retrieved from http://www.ta.doc.gov/digeconomy/framewrk.htm (2003)

18.Zippo Manufacturing Co. v. Zippo Dot Com, Inc., 952 F. Supp. 1119, 1121 (W.D. Pa. 1997). 